\title{
A PALEONTOLÓGIAI BIZOTTSÁG ÁLLÁSFOGLALÁSA A NÖVÉNYTÁR ÜGYÉBEN
}

Az MTA Paleontológiai Tudományos Bizottsága 2018. február 17-én támogatólag csatlakozott Podani János akadémikus (Diverzitásbiológiai Bizottság) elöterjesztéséhez a Magyar Természettudományi Múzeum Növénytárának helyzetéről, a helyzet megoldására tett javaslatokkal együtt, az alábbi, módosított állásfoglalással.

A Bizottság állásfoglalását az alábbiakban rögzíti, és kéri az MTA Földtudományok Osztálya támogatását a 2018. február 20-i ülésén:

- Az Emberi Eröforrások Minisztériuma haladéktalanul függessze fel a Növénytár területének további csökkentését elrendelö intézkedését.

Értékelésünk szerint ez teljesen ellehetetleníti az adott intézmény hazai és regionális tudományos és közmüvelödési feladatainak ellátását, illetve az ott örzött és gondozott pótolhatatlan nemzeti kincs értékü herbárium és paleobotanikai anyagok és jeles elődeink hagyatékának további fennmaradását. A botanika és paleobotanika szakterületein ez nemcsak az ország és a Kárpát-medence, hanem a Balkántól a Baltikumig terjedő egész Kelet-Közép-Európai Régió legjelentősebb tudományos gyüjteménye, így kiemelt figyelmet érdemel az MTA és a Kormány szintjén egyaránt.

- Halaszthatatlannak tartjuk az egész Magyar Természettudományi Múzeum helyzetének minden oldalú (épület, infrastruktúra, kutatói, megőrző és közmúvelődési személyi állomány, főhatóság) végleges, a jelenlegi európai gyakorlat élvonala szintjének megfelelö megoldását.

Javasoljuk, hogy alakuljon meg egy előkészítő bizottság az MTA felügyeletével, amely a teljes MTM helyzetét felméri, és javaslatokat fogalmaz meg a Múzeum helyzetének javítására, illetve egy mielőbbi végleges megoldás kidolgozására - összhangban az Akadémiai törvény és alapszabály megfelelő kitételeivel. Ezt követően az MTA és a kormány együttes, sürgös és összehangolt intézkedéseire lenne szükség. 